\title{
KONSEP NEGARA UTAMA AL-FARABI DAN RELEVANSINYA
}

\author{
SUNARYO*
}

\begin{abstract}
Abstrak: Dalam artikel ini penulis mengeksplorasi gagasan kota utama yang diajukan oleh Abu Nashr al-Farabi (870-950 M), seorang filsuf Muslim di abad ke-10. Gagasan al-Farabi mengenai kota utama banyak

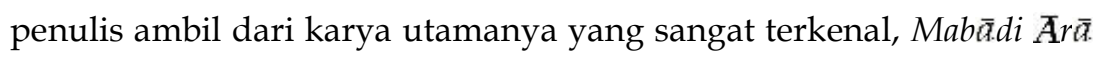
Ahl al-Madrinah al-Fādhilah yang secara harafiah berarti "Dasar-dasar Pandangan Warga Kota Utama." Pandangan al-Farabi dalam karya ini banyak dipengaruhi oleh dua filsuf Yunani, yakni Plato dan Aristoteles. Kota utama adalah kota yang warganya mengerti hakikat kebenaran (teoritis) dan juga memiliki kemampuan bertindak secara moderat (tawassuth) dengan mempertimbangkan tempat, waktu, pelaku dan juga alasan mengapa hal itu perlu dilakukan (phronesis). Keutamaan ini bisa mengantarkan para warganya untuk mencapai kebahagiaan ( $\left.a l-s a^{\prime} \bar{a} \cdot d a h\right)$. Kebahagiaan adalah tujuan hidup yang paling utama dan paling tinggi bagi manusia. Bagi al-Farabi, dalam upaya mewujudkan kota utama, peran filsuf raja menjadi sangat penting karena dia yang akan mendidik para warga untuk mengerti dan bisa bertindak sesuai dengan nilai-nilai keutamaan.
\end{abstract}

Kata-kata Kunci: Kota utama, kebahagiaan, emanasi, neoplatonisme, penyatuan, phronesis.

Abstract: In this article I will explore al-Farabi's idea of virtuous city. Abu Nashr Al-Farabi is a Muslim philosopher who lived in 870 to 950. The idea of virtuous city much refers to his master piece, Maba $\bar{a} d i \bar{A} r \bar{a}$. Ahl

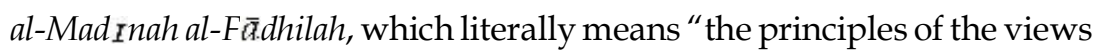
of citizens in virtuous city." Al-Farabi's concept of virtuous city in this book is much influenced by two Greek philosophers, i.e. Plato and Aristoteles. The virtuous city is the city in which the virtuous citizens

* Sunaryo, Fakultas Falsafah dan Peradaban, Universitas Paramadina, Jl. Gatot Subroto Kav.97, Mampang, Jakarta 12790. Email: sunaryo@paramadina.ac.id. 
live. The virtuous citizens are those who understand the nature of truth and have virtuous character (phronesis). This virtue will carry the citizens to happiness (al-sa'adah). The happiness is the ultimate goal for all human beings. According to al-Farabi, to make virtuous city happen, the role of philosopher-king is very important. He will teach and educate the people to understand the nature of truth and act in accordance with virtuous character.

Keywords: Virtuous City, happiness, emanation, Neoplatonism, union, phronesis.

\section{PENDAHULUAN}

Jika kita membaca filsafat dari kalangan filsuf Muslim, kita akan menjumpai pertautan dan percampuran ide dari berbagai tradisi. Salah satunya tentu saja pengaruh filsafat Yunani. Tidak terlalu sulit untuk melihat adanya pengaruh filsafat Yunani dalam karya-karya filsuf Muslim, karena sejak abad kesembilan telah terjadi penerjemahan yang cukup masif dari bahasa Yunani ke bahasa Arab. ${ }^{1}$ Salah satu masa yang dicatat sebagai masa akuisisi yang sangat masif terjadi di masa Bani 'Abbasiyah, khususnya pada era Khalifah al-Ma'mun yang berkuasa dari 813 hingga $833 \mathrm{M}$. Di masanya, sebuah perpustakaan besar bernama Bayt al-Hikmah didirikan di Baghdad dan kemudian menjadi pusat penerjemahan dan pusat kegiatan intelektual di masa itu. ${ }^{2}$ Menurut Frederick Meyer, perpustakaan Bayt al-Hikmah adalah perpustakaan yang sangat bagus yang kemegahannya tidak didapatkan di dalam kebudayaan Eropa Barat saat itu. ${ }^{3}$ Buku-buku yang diterjemahkan di masa itu terdiri dari berbagai bahasa, mulai dari bahasa Yunani, Suryani, Persia, Ibrani, India, Qibti, Nibti dan Latin. ${ }^{4}$ Buku-buku berbahasa

1 Penerjemahan buku-buku non-Arab ke dalam bahasa Arab terjadi secara besarbesaran dari awal abad kedua hingga akhir abad keempat hijriyah. Jamil Shaliba, alFalsafah al-'Arabiyah, (Beirut: Dar al-Kitab al-Lubnani, 1973), p. 96

2 Harun Nasution, Islam Ditinjau Dari Bebabagi aspeknya, Jilid I, (Jakarta: UI Press, 1985), hlm. 68.

3 Frederick Meyer, A History of Ancient and Medieval Philosophy, (New York: American Book Company, 1950), p. 391. 
Yunani adalah yang paling diminati, dan karya yang paling banyak diterjemahkan ke dalam bahasa Arab adalah karya-karya Plato dan Aristoteles.

Buku al-Madīnah al-Fādhilah karya al-Farabi adalah salah satu karya monumental filsafat Islam yang sangat dipengaruhi oleh filsafat Yunani. Buku ini berbicara mengenai banyak hal yang terkait problem-problem dasar filsafat seperti metafisika, alam, psikologi (manusia), epistemologi, etika, politik dan eskatologi. Dalam artikel singkat ini, penulis akan mengajak pembaca untuk melihat gagasan yang dituangkan dalam buku ini. Sesuai judulnya, buku ini sebenarnya ingin menunjukkan pandangan para warga kota utama. Ia memahami keutamaan dalam arti teoritis dan sekaligus praktis. Di sini ia juga menunjukkan peran penting seorang filsuf sebagai pribadi yang mengerti makna keutamaan. Karenanya, sebagaimana Plato, ia juga mengidealkan bahwa pemimpin itu adalah seorang filsuf, yang dengan posisi itu ia bisa mendidik warga agar bisa mengerti dan juga bertindak dengan nilai-nilai keutamaan. Selanjutnya, penulis mencoba mengangkat relevansi yang bisa diambil dari kajian atas kota utama al-Farabi. Salah satu tantangan yang perlu direspon saat ini adalah soal fakta pluralitas atau keragaman nilai dalam masyarakat. Bagaimana ide kota utama bisa merespon dan menjawab soal ini akan penulis singgung di bagian akhir tulisan.

\section{AL-FARABI DAN KARYANYA}

Abu Nashr Al-Farabi dalam literatur Latin dikenal dengan nama Alpharabius. Ia lahir pada 870 di Wasij, yang menjadi bagian dari distrik Farab, Turkistan, dan meninggal pada $950 .{ }^{5}$ Filsafat al-Farabi tidak bisa dipisahkan dari Aristoteles, khususnya pada bidang logika, fisika dan metafisika. Karenanya kemudian ia diberi gelar sebagai Guru Kedua (al-Mu'allim al-Tsāni) setelah Aristoteles — yang menjadi al-Mu'allim al-

4 Shaliba, al-Falsafah al-'Arabiyah, p. 95

5 Richard Walzer, "Introduction" pp. 1-18, dalam Richard Walzer, Al-Farabi on the Perfect State, Teks Revisi, Pengantar, Terjemahan dan Komentar, (Oxford: Clarendon Press, 1985) p. 2. 
Awwal. Ia belajar logika dari seorang ahli di masa itu, yakni Abu Bisyr ibn Matta. Karyanya yang membahas logika Aristoteles dapat dilihat dalam beberapa karya penting, di antaranya adalah Introductory Treatise (Risālah "̄'l-Tawti'ah), The Five Sections (al-Fusīl al-Khamsah), Terms Used in Logic (al-Alfāzh al-Musta'malah $f_{I}$ al-Mantiq) dan the Book of Letters (Kitab a l-Huruf). Ia juga membahas materi-materi filsafat Aristoteles yang lain seperti fisika dan meteorologi, yang bisa dilihat dalam komentarnya

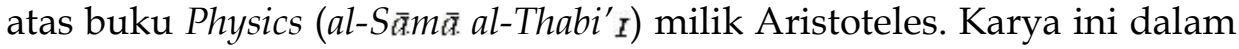
literatur Arab dikenal dengan judul Treatise on Changing Entities ( $F_{I}$ alMaujüdat al-Mutaghayyirah), the Heavens and the world (al-Samā' wa alAlam), dan Meteorology (al-Atsar al-'alawiyah). ${ }^{6}$

Karya-karya mengenai metafisika di antaranya adalah Treatise on Metaphysics (F⿳亠口冋 al-'Ilm al-Ilā $h \bar{I})$ dan Harmony of the Opinions of Plato and

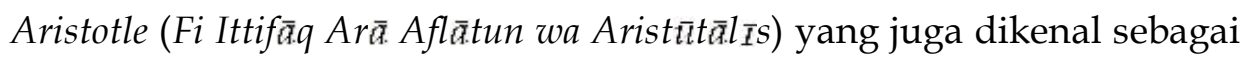
al-Jam' bayn al-Hākimayn. Selain materi-materi filsafat di atas, al-Farabi juga memberikan perhatian pada musik. Ia menulis sebuah buku Musical

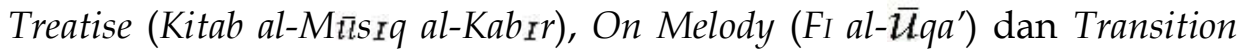
to Melody (al-Nuqlah ila al- $\left.\overline{\mathcal{u}} q \bar{a}^{\prime}\right){ }^{7}$ Menurut Majid Fakhry, filsafat al-Farabi sangat dipengaruhi oleh Aristoteles, Plato dan filsuf pra-Sokrates. Kecenderungan untuk merekonsiliasi Plato dan Aristoteles banyak diinspirasi oleh filsuf Helenis, khususnya Phorphyry (w. 304), murid Plotinus, pendiri Neoplatonisme. Al-Farabi menjadi orang pertama yang memperkenalkan neoplatonisme di dunia Muslim. ${ }^{8}$ Masa al-Farabi dan pemikir yang menjadi pengikut dan pengembang ajarannya adalah salah satu fase yang paling kaya secara intelektual. Masa itu kerap disebut sebagai "Farabisme," fase yang berlangsung sejak kelahirannya pada tahun 870 M hingga kematian Abu Hayyan at-Tawhidi pada 1023 M. ${ }^{9}$

6 Majid Fakhry, Al-Fāāābi: Founder of Islamic Neoplatonism, (Oxford: One World, 2002), p. 8.

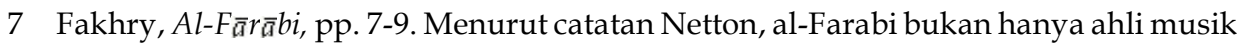
secara teoritis. Ia juga merupakan orang yang pandai memainkan alat-alat musik.

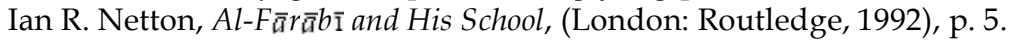

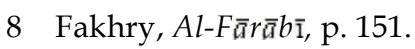

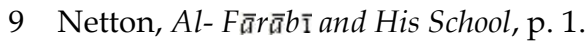




\section{NEOPLATONISME DAN TEORI EMANASI}

Filsafat al-Farabi tidak bisa dipisahkan dari ajaran Neoplatonisme yang dikembangkan oleh Plotinus. Salah satu karya pertama dari tradisi neoplatonisme yang diterjemahkan ke dalam bahasa Arab adalah The Theology of Aristotle atau Kitab āl-Rububiyāh (Book of Divinity). Penerjemahnya adalah Abd al-Masih ibn Na'imah al-Him'ı. Dalam studi-studi terakhir kita mengetahui bahwa karya yang diterjemahkan itu sebenarnya adalah parafrase dari tiga bagian akhir karya Plotinus Enneads, bagian IV, V dan VI. Karya ini kemungkinan besar ditulis oleh murid Plotinus yakni Porphyry, penulis buku terkenal Isagoge (pengantar karya Categories of Aristotle). Buku Theology ini dibaca oleh banyak filsuf Muslim saat itu. Karya ini pernah dikomentari oleh al-Kindi, Ibn Sina dan lainlain. Karya ini juga banyak dikutip oleh al-Farabi dalam Reconciliation of Plato and Aristotle. Karya neoplatonisme lain yang juga beredar di kalangan filsuf berbahasa Arab adalah al-Khayr al-Mahdh (the Pure Good) yang ditulis oleh seorang neoplatonis Yunani, Proclus (w. 485). Hingga saat ini, penerjemah karya ini tidak diketahui. ${ }^{10}$

Menurut Fakhry, melalui dua karya ini ide neoplatonisme masuk ke dalam pemikiran filsuf Muslim. Al-Farabi termasuk orang pertama yang mengkaji, mempelajari dan dipengaruhi oleh ajaran itu secara mendalam. Salah satu teori al-Farabi yang sangat dipengaruhi ajaran neoplatonisme adalah teori emanasi (al-Faydh atau al-Shudür). Lewat teori itu ia memberikan penjelasan tentang fase transisi (means ofbridging) dari dunia intelligible ke dunia material. Dalam teori ini ia menjelaskan bagaimana alam semesta terbentuk dari Yang Satu (the One, first Principle/to Hen) turun ke intelek (nous), jiwa (psyche) dan alam material secara berurutan. ${ }^{11}$

Dalam buku al-Madınah al-Fāadhilah, al-Farabi menjelaskan proses emanasi dari Yang Satu ke akal pertama. Pada bagian paling pertama

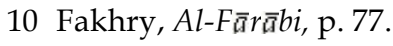

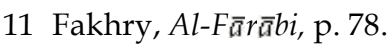


buku itu ia menguraikan tentang wujud pertama, the First Being (alAwwal) yang menjadi penyebab dari segala yang ada. Ia menyebut Yang Satu ini sebagai Yang Paling Baik dan Yang Paling Awal. Tidak ada yang lebih baik dan lebih awal dibanding Yang Satu ini. Sepenuhnya, Yang Satu ini terbebas dari segala ketidaksempurnaan dan ketiadaan. Karenanya, Ia abadi dan cukup diri (self-sufficient). Menurutnya, Yang Satu tidaklah disebabkan oleh sesuatu yang lain dan Ia tidak memiliki bentuk (form), karena jika Ia memiliki bentuk maka Ia harus berada dalam materi, dan itu tidak mungkin. Selain itu, Ia juga tidak memiliki sekutu dalam kesempurnaan: ${ }^{12}$

“Wujud yang pertama adalah penyebab pertama bagi segala yang ada. Ia bebas dari segala kekurangan. Wujudnya adalah yang paling utama dan paling dahulu, dan (karenanya) tidak mungkin ada wujud yang lebih utama dan lebih dahulu daripada wujud-Nya. Karenanya (pula), mustahil jika terdapat ketiadaan pada wujud dan substansi-Nya."13

Penyebab pertama ini disebut sebagai wajib al-wujud (Yang Wajib Ada/The Necessary Existent). Darinya kemudian lahir wujud kedua, yakni entitas non-corporeal dan non material. Ia disebut sebagai intelek (the second being). Semua yang lahir dari wujud pertama (wajib al-wujud) disebut sebagai Mumkin al-Wujūd (Yang Mungkin Ada/The Contingent Being).Ia disebut Mumkin al-Wujūid dalam arti bahwa ia tidak mungkin muncul kecuali karena ada penyebabnya. Kemudian, penyebab itu juga didahului oleh penyebab sebelumnya, namun mustahil jika penyebab ini tidak berkesudahan. Karenanya, penyebab ini harus berhenti pada penyebab yang tidak disebabkan oleh yang lain. Penyebab ini disebut sebagai penyebab pertama (prime cause). ${ }^{14}$ Proses kemunculan segala sesuatu secara berurutan dari wujud pertama disebut sebagai emanasi (al-Faydh atau al-Shudur).

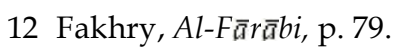

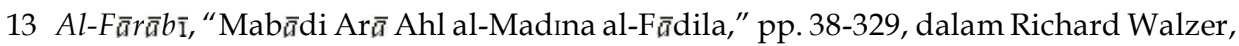
Al-Farabi on the Perfect State, Teks Revisi, Pengantar, Terjemahan dan Komentar, (Oxford: Clarendon Press, 1985), p. 56.

14 Jamil Shaliba, Tarikh al-Falsafah al-'Arabiyah, (Beirut: Dar al-Kitab al-Lubnani, 1970), p. 147. 
Secara lebih detail, Al-Farabi menjelaskan teori emanasinya seperti ini: Wujud Pertama memikirkan zat-Nya, maka lahirlah Wujud Kedua yang kemudian menjadi Akal Pertama. Akal Pertama ini merupakan substansi yang tidak berbadan sama sekali dan tidak berada pada materi. Jika Akal Pertama memikirkan zatnya dan Wujud Pertama, maka akan lahir Akal Kedua. Bersamaan dengan munculnya akal kedua ini

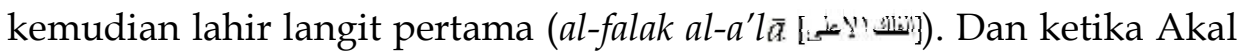
Kedua ini memikirkan zatnya dan Wujud Pertama, maka akan muncul

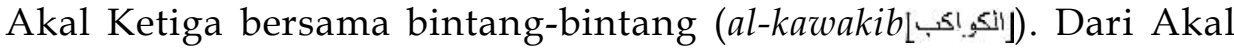
Ketiga kemudian melahirkan Akal Keempat bersama planet Saturnus

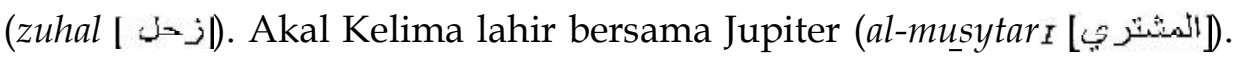
Akal Keenam bersama Mars (al-marrkh [النسين [ ]). Akal Ketujuh bersama Matahari (al-syams [ التثنس]). Akal Kedelapan bersama Venus (al-zuhrah

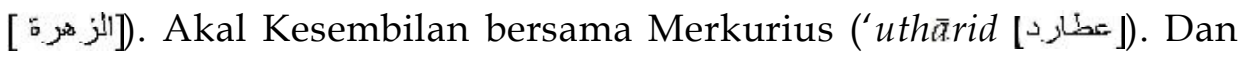
pada akal kesepuluh atau yang terakhir bersama Bulan (al-qamar

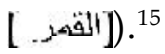

Akal-akal ini, oleh al-Farabi disebut sebagai "dunia atas bulan." Akal-akal ini adalah wujud yang tidak membutuhkan tempat dan materi sama sekali. Bulan (lunar) menjadi batas bagi benda-benda langit yang geraknya melingkar itu. ${ }^{16}$ Sementara dunia yang berada di bawah bulan atau yang disebut dunia sublunar memiliki sifat kekurangan. Dunia di bawah bulan ini berada dalam dimensi waktu. Yang termasuk bagian dari isi dunia sublunar ini adalah api, udara, air, tanah (yang kemudian disebut sebagai unsur yang empat), barang tambang, tumbuh-tumbuhan, mahluk non-rasional dan mahluk rasional. ${ }^{17}$ Dalam teori emanasi, posisi intelek menempati posisi yang tinggi dan menjadikan psyche sebagai penghubung antara intelek dan dunia material. Al-Farabi mema-

15 Al-Farabi, “al-Madīna," pp. 100-104. bdk. Jamil Shaliba, al-Falsafah al-'Arabiyah p. 151 dan Majid Fakhry, Sejarah Filsafat Islam: Sebuah Peta Kronologis, 2001, (Bandung: Mizan, 2001) diterjemahkan dari karya A Short Introduction to Islamic Philosophy, Theology and Mysticism, pp. 48-9.

16 Al-Farabi, “al-Madīna," p. 104.

17 Al-Farabi, “al-Madīna,” pp. 106-8. 
hami proses emanasi ini sebagai proses yang berlangsung dalam keabadian. Pandangan ini, nantinya akan menjadi sumber kontroversi di kalangan teolog Muslim karena mengeksklusi dua proposisi dasar yang diyakini oleh para teolog saat itu yakni bahwa alam semesta itu diciptakan Tuhan dari ketiadaan dan proses itu berlangsung di dalam waktu. Pandangan teolog ini pada umumnya didasarkan pada ayat al-Quran yang mengisahkan proses penciptaan. ${ }^{18}$

\section{BUKU “AL-MADĪNAH AL-FADDHLAH"}

Mabādi Arā Ahl al-Madīnah al-Fāadhilah (Dasar-dasar Pandangan Warga Kota Utama) adalah judul lengkap buku al-Madınah al-Fādhılah, karya al-Farabi yang paling terkenal. Menurut Walzer, karya yang ditulis pada abad kesepuluh ini bukanlah terjemahan atau adaptasi dari karya Yunani. Ia juga bukanlah manual pengajaran. Isinya lebih dimaksudkan oleh penulisnya sebagai perkenalan untuk masyarakat Muslim mengenai politik, keagamaan dan pemikiran/intelektualitas. Menariknya, pandangan yang ia sajikan di dalam buku ini tidak berakar pada pemikiran Arab atau Islam. Ia justru mengakarkan pandangannya pada filsafat Yunani. Pandangan-pandangannya banyak dipengaruhi oleh Plato dan Aristoteles, dan pemahaman para pemikir Yunani sebelum dan sesudah Plotinus. ${ }^{19}$

Isi buku ini terdiri dari tiga fasal utama, yakni tentang teologi (metafisika), tentang benda-benda alam (fisika) dan tentang tindakan (etika). Tiga fasal ini kemudian dijabarkan dalam sembilan belas bab. Isi pokok sembilan belas bab itu adalah sebagai berikut. Pada bab pertama, alFarabi menjelaskan tentang penyebab segala hal yang ada di alam semesta, yakni Tuhan semesta alam. Realitas yang wajib dipercaya dan diyakini ini disebut sebagai hal yang wajib ada (wājib al-wujūid). Bab kedua adalah tentang realitas malaikat yang juga wajib dipercaya. Darinya kemudian

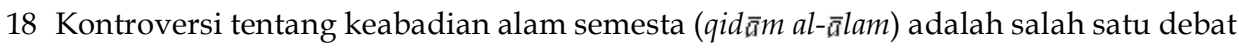
paling panas dalam sejarah teologi Islam. Lih. Dalam al-Ghazali, Tah̄̄afut al-Fal̄̄sifah, Sulaiman Dunyā (ed.) (Kairo: Dār al-Ma'ārif, 1972).

19 Walzer, "Introduction," p. 6. 
muncul benda-benda langit. Ketiga adalah tentang benda-benda langit (al-ajsām al-samāwwiyah/heavenly bodies). Keempat tentang benda-benda yang ada di bawah bulan, yakni benda-benda material (al-ajsām alhayülāniyah/material bodies). Kelima tentang materi dan bentuk yang merupakan komposisi dari segala substansi. Keenam tentang susunan realitas dari paling bawah (sublunar) hingga paling tinggi (realitas yang ada di atas bulan). Ketujuh tentang sifat benda-benda langit. Kedelapan, penjelasan mengenai terciptanya benda-benda material, dari yang pertama kali muncul hingga kemudian muncul manusia. Kesembilan tentang sifat benda-benda di bawah bulan (sublunar). ${ }^{20}$

Selanjutnya pada bab kesepuluh al-Farabi menjelaskan tentang manusia dan kemampuan atau potensi dari jiwa manusia. Kesebelas tentang fungsi-fungsi organ dalam tubuh manusia. Keduabelas tentang peran-peran organ reproduksi antara laki-laki dan perempuan. Ketigabelas tentang kemampuan berpikir pada manusia (rasio). Di sini dijelaskan tentang beragam kapasitas yang dimiliki oleh akal. Keempatbelas dijelaskan mengenai kapasitas representasi (al-mutakhayyilah). Ia adalah perantara antara kemampuan inderawi dan kemampuan rasional. Kelimabelas tentang kebutuhan manusia untuk hidup bersama dan saling membantu. Di sini dijelaskan mengenai asosiasi/perkumpulan (ijtim $\left.\bar{a}^{\prime}\right)$ sempurna, pemimpin sempurna dan asosiasi/perkumpulan yang salah. Keenambelas adalah penjelasan mengenai kebahagiaan yang paling tinggi, yakni kehidupan di akhirat nanti. Ketujuhbelas tentang hal yang harus ada dalam kota utama. Kedelapanbelas tentang pandangan-pandangan salah yang memunculkan asosiasi dan kota yang salah. Kesembilanbelas tentang prinsip-prinsip yang salah yang darinya kemudian muncul agama yang sesat. ${ }^{21}$ Jika dikaitkan dengan judul bukunya, “Prinsip-prinsip Dasar Pandangan Warga Kota Utama," maka keseluruhan isi buku ini sebenarnya adalah satu kesatuan hal yang harus diketahui dan diyakini oleh warga kota utama. Pengetahuan mengenai hal ini disebut sebagai keutamaan teoritis.

20 Al-Farabi, “al-Madina," pp. 38-42.

21 Al-Farabi, “al-Madina," pp. 42-48. 


\section{KONSEP KOTA UTAMA}

Konsep kota utama menjadi konsep sentral dalam buku al-Madınah al-Fādhilah. Hal yang tidak bisa dihindari dari bahasan ini adalah pandangannya mengenai konsep etika. Sama seperti Aristoteles, alFarabi menempatkan kebahagiaan ( $a l-s a^{\prime} \bar{a}$ dah) sebagai tujuan hidup manusia dan menjadi ide utama dalam pandangan etikanya. ${ }^{22}$ Menurutnya, tujuan tertinggi yang harus diraih oleh manusia adalah kebahagiaan. Di sini kebahagiaan tertinggi lebih dipahami sebagai penyatuan (union) dengan akal aktif (active intellect) yang menjadi sumber dari segala hal yang dapat dipikirkan (intelligible). Ia menyebut fase penyatuan ini sebagai ittishal atau qurb, yakni puncak dari seluruh kebahagiaan yang dikejar oleh manusia. Ia memahami konsep akal aktif ini sebagai al-Ruh al-AmIn, Jibril dan al-Ruh al-Quds.Menurut al-Farabi, sarana untuk mencapai tujuan (tahshIl al-sa'adah) ini ada empat, yakni melalui jalan teoritis, reflektif, etis dan politis. Ia menyebut sarana ini sebagai empat tipe keutamaan (four types of virtue). ${ }^{23}$

Yang dimaksud dengan keutamaan teoritis adalah semua pengetahuan yang tujuan tertingginya adalah untuk mengetahui entitas yang bersifat intelligible. Sementara keutamaan etis atau praktis lebih dipahami sebagai kemampuan untuk membedakan antara yang baik dan yang buruk (tamyIz). Tindakan ini merupakan turunan dari tindakan yang sesuai dengan tuntutan intelektual. Katanya, seseorang akan dicela jika tidak mampu memfungsikan daya intelektual sebagaimana mestinya. Menurutnya, kemampuan itu hanya mungkin jika seseorang sudah bisa membiasakan sesuatu sebagaimana mestinya sehingga menjadi habitus (malakah). Di fase ini seseorang akan dengan mudah melakukan tindakan pembedaan antara yang baik dan yang buruk. Manusia yang sudah mencapai kemampuan ini akan selalu terlindungi dari hal-hal yang secara moral bersifat jahat, dan akan selalu tertuntun pada jalan

22 Dalam Nichomachean Ethicskonsep ini disebut sebagai eudaimonia. Lih. Aristotle, Nicomachean Ethics, diterjemahkan dan diedit oleh Roger Crisp, (Cambridge: Cambridge University Press, 2004), p. 206.

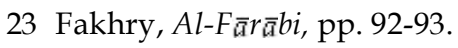


yang membawa pada kebahagiaan. Dengan demikian, karakter yang baik dan kemampuan membedakan antara yang buruk dan yang baik menjadi prasyarat esensial untuk meraih kebahagiaan di level praktis. ${ }^{24}$

Menurut al-Farabi, yang dimaksud dengan karakter adalah kemampuan untuk mengembangkan watak/sifat (isti'd $\bar{a} d$ ) yang bisa memilih hal baik dan menghindari hal buruk. Jika ada pertanyaan, apakah sifat utama itu bersifat alamiah ataukah hasil pendidikan, maka jawabannya adalah bahwa manusia secara alamiah sebenarnya diberi kemampuan untuk meraih sifat utama dan juga kemampuan teknis. Karakter keutamaan yang paling tinggi adalah kemampuan untuk bersikap moderat (tawassuth) dengan mempertimbangkan tempat, waktu, pelaku dan juga alasan mengapa hal itu perlu dilakukan. Misalnya sikap keberanian adalah sikap moderat antara sikap ceroboh/nekat dan pengecut, atau sikap dermawan adalah sikap moderat antara sikap boros dan kikir. ${ }^{25}$ Aristoteles menyebut kemampuan ini sebagai phronesis, yakni kemampuan untuk bertindak secara tepat dan pas dari segi waktu dan tempat.

Dengan demikian, dalam pandangan al-Farabi, yang etis atau "the good" itu memiliki dua sisi. Pertama, pengetahuan demi dirinya sendiri; kedua pengetahuan yang dikaitkan dengan tindakan. ${ }^{26}$ Dengan kata lain, filsafat dibagi menjadi dua bagian, teoritis dan praktis. Dua sisi ini, pengetahuan teoritis yang menjadi sarana untuk meraih kebahagiaan dan tindakan yang menjadi pra-kondisi untuk meraih kebahagiaan akan dianggap sebagai bagian dari filsafat. ${ }^{27}$ Seorang filsuf, bagi al-Farabi adalah pewujudan dari konsep manusia sempurna (al-insān al-kāmil). ${ }^{28}$

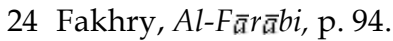

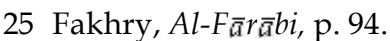

26 Dalam konteks etika Aristoteles, Alasdair MacIntyre menjelaskan perbedaan antara keutamaan intelektual (intellectual virtue) dan keutamaan karakter (virtues of character). Katanya, keutamaan intelektual diperoleh lewat pengajaran (teaching) dan keutamaan karakter diperoleh lewat pembiasaan (habitual exercise). Lih. Alasdair MacIntyre, After Virtue: A Study in Moral Theory, edisi ketiga, (Indiana: University of Notre Dame Press, 2007 [1981]), p.154.

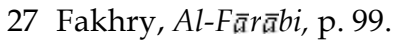

28 Richard Walzer, “Commentary,"pp. 331-503, dalam Richard Walzer, Al-Farabi on the 
Seorang filsuf bukanlah orang yang menarik diri dari kehidupan sosial dengan hanya memikirkan pencapaian kebahagiaan untuk dirinya sendiri. Seorang filsuf harus melibatkan diri dengan persoalan pemerintahan dan legislasi untuk memberikan pencerahan kepada para non-filsuf. ${ }^{29}$ Seorang filsuf adalah guru moral yang memiliki tanggung jawab untuk memperbaiki hal yang dianggap lemah (secara moral) dari seorang murid..$^{30}$

Dari konsepsi mengenai etika, al-Farabi kemudian masuk pada pandangan mengenai "negara" atau tatanan sosial. ${ }^{31}$ Karena seorang filsuf adalah orang yang mengerti tentang hakikat segala sesuatu sebagaimana adanya, maka yang layak untuk menjadi pemimpin dalam sebuah negara adalah seorang filsuf. Pandangan ini tentu saja banyak dipengaruhi oleh Plato tentang filsuf-raja (philosopher-king). ${ }^{32}$ Dalam menjelaskan tatanan sosial ia menyebut istilah kunci yang kemudian menjadi judul bukunya yakni al-Madīnah al-Fādhilah. Secara etimologi, al-madīnah

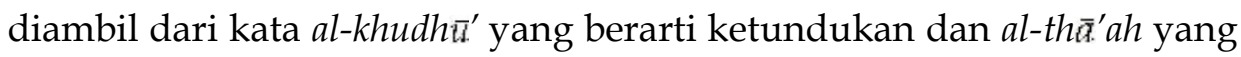

Perfect State, Teks Revisi, Pengantar, Terjemahan dan Komentar (Oxford: Clarendon Press, 1985), p. 423. Dalam al-Madinah, al-Farabi menjelaskan perbedaan antara seorang filsuf dan seorang agamawan. Seorang filsuf adalah orang yang mengetahui realitas sebagaimana adanya, sementara seorang agamawan adalah orang yang bisa mengetahui realitas melalui simbol dan perumpamaan. Lih. Al-Farabi, "al-Madīna," p. 278.

29 Walzer, "Commentary," p. 427.

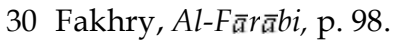

31 Rumusan mengenai etika menjadi sentral bagi filsafat politik, karena etika berbicara mengenai apa yang dianggap sebagai "baik" / the good. Sementara institusi sosial kemudian menjadi sarana untuk merealisasikan apa yang dianggap baik kepada publik. Sebagaimana dikutip dari Aristoteles, "Tujuan sebuah polis adalah kehidupan yang baik, dan institusi kehidupan sosial adalah sarana untuk tujuan tersebut." Lih. Michael J. Sandel, Justice: What's the Right Thing To Do? (New York: Farrar, Straus and Giroux, 2009), p. 194.

32 Dalam pengalaman Plato, Sokrates dihukum mati pada 399 SM oleh rezim demokrasi karena dianggap mengancam keyakinan negara dengan cara meracuni pikiranpikiran warganya. Dari sini ia kemudian berpandangan bahwa tidak ada pemerintahan yang baik hingga seorang filsuf memimpin pemerintahan itu atau hingga seorang pemimpin sudah menjadi filsuf. Lih. G. R. F. Ferrari, "Pengantar" dalam Plato, The Republic, diedit oleh G. R. F. Ferrari, diterjemahkan oleh Tom Griffith, (Cambridge: Cambridge University Press, 2000), pp. xii-xiii. 
berarti ketaatan, dan al-jar $\bar{a}^{\prime}$ yang berarti penunaian. ${ }^{33}$ Sementara yang dimaksud dengan kota utama, merujuk pada pendapat para filsuf sebelumnya, adalah kota yang warganya memiliki pandangan-pandangan utama. ${ }^{34}$ Keutamaan (virtuous) yang dimaksud adalah nilai etis sebagaimana sudah dijelaskan di atas.

Dalam merumuskan konsep politik, al-Farabi menjelaskan bagaimana sebuah masyarakat terbentuk pertama kali. Pandangannya mengenai masyarakat (ijtimā' $\bar{a} \cdot$ ) banyak dipengaruhi oleh Plato. Katanya, setiap manusia secara alamiah membutuhkan manusia yang lain untuk memenuhi segala kebutuhannya. Manusia tidak bisa memenuhi kebutuhannya sendiri. Karenanya, masyarakat (ijtimāa $\bar{a} \cdot t)$ bagi spesis manusia adalah sebuah keniscayaan di mana di dalamnya mereka saling membantu untuk memenuhi kebutuhan. ${ }^{35}$ Menurut Walzer, pandangan bahwa kerjasama sosial merupakan keniscayaan bagi manusia diterima oleh para pengikut Plato dan juga Aristoteles. ${ }^{36}$ Dalam buku Politeia atau Republic, Plato menulis:

“Ya, menurut saya awal mula negara terjadi ketika kita tidak merasa cukup pada diri sendiri (self-sufficient)... individu yang berbeda berasosiasi untuk memenuhi satu kebutuhan dan dengan orang lain untuk memenuhi kebutuhan yang lain. Dalam keragaman kebutuhan ini mereka kemudian mengumpulkan kawannya untuk menempati satu tempat tinggal bersama. Tempat tinggal bersama inilah yang kemudian disebut negara. Bukankah ketika seseorang berbagi dan saling bertukar itu justru lebih baik secara personal?" 37

Dari ucapan ini kita dapat menyimpulkan bahwa bagi Plato, terbentuknya negara adalah karena tidak ada manusia yang bisa memenuhi

33 Al-Farabi, “al-Madina,” p. 50. Walzer memahami istilah madinah sama dengan konsep negara-kota atau polis. Ia adalah satu masyarakat yang ditata dan memiliki independensi secara politik. Lih. Walzer, “Commentary," p. 430.

34 Al-Farabi, “al-Madına,” p. 52.

35 Al-Farabi, “al-Madina," p. 228

36 Walzer, "Commentary," p. 429

37 Plato, The Republic, diedit oleh G. R. F. Ferrari, diterjemahkan oleh Tom Griffith, (Cambridge: Cambridge University Press, 2000) bab 2, 369a-d 
kebutuhannya sendirian. Ia menambahkan bahwa "...kebutuhan yang paling penting untuk kelangsungan hidup adalah penyediaan makanan." 38 Pandangan dasar ini juga diafirmasi oleh Aristoteles. Katanya “...negarakota adalah di antara sesuatu yang ada secara alamiah, sehingga manusia (juga) secara alamiah merupakan mahluk sosial (zoon politikon)." Dalam pandangannya, hanya ada dua kemung-kinan jika ada mahluk yang hidup tanpa negara-kota atau tidak bersosial. Kemungkinan pertama mereka adalah spesis yang lebih rendah dari manusia, dan kemungkinan kedua mereka adalah spesis manusia super (seperti malaikat). ${ }^{39}$

Tentang varian masyarakat, al-Farabi menjelaskan lebih lanjut bahwa masyarakat yang terbentuk itu ada yang sempurna (al-kāmilat) dan tidak sempurna (ghayr al-kāmilat). Katanya, yang sempurna itu ada tiga skala, yakni besar ('uzhmāa), sedang (wusthā) dan kecil (shughrā). Yang besar itu adalah kesatuan bangsa-bangsa dalam satu masyarakat dunia (al-ma'mûrah/s'ألمعيور). Yang sedang adalah kesatuan satu bangsa (الأ ) yang merupakan bagian dari yang global. Dan yang kecil adalah kesatuan warga kota (المدينة) yang merupakan bagian dari bangsa. ${ }^{40}$ Dari tiga ukuran ini kita bisa melihat bahwa satuan politik sempurna terkecil adalah negara kota (city states), kemudian negara bangsa (nation states) dan yang terbesar adalah negara global. ${ }^{41}$ Sementara yang tidak sempurna (ghayr al-kāmilat) adalah persekutuan warga yang lebih kecil dari negara kota, yakni warga desa, persekutuan warga di sebuah jalan, persekutuan di sudut tempat dan yang paling kecil adalah persekutuan di rumah. ${ }^{42}$

Dalam pandangan al-Farabi, yang paling utama dan paling baik adalah ukuran kota, bukan yang lebih kecil dari itu. ${ }^{43}$ Ia menjelaskan

38 "And the first and most important of those needs, if we are to exist and stay alive, is the provision of food" Lih. Plato, The Republic, bab. 2, 369d.

39 Aristotle, Politics, diterjemahkan oleh C.D.C. Reeve, (Cambridge: Hacket Publishing Company, 1998), 1253a 1-4

40 Al-Farabi, “al-Madina,” pp. 228-230.

41 Walzer, "Commentary," p. 430.

42 Al-Farabi, “al-Madına,” p. 230.

43 Al-Farabi, “al-Madına," p. 230. 
lebih lanjut bahwa dalam sebuah kota, warganya bisa bekerjasama untuk kebaikan dan bisa juga untuk kejahatan. Karenanya, tidak semua kota dibentuk untuk meraih kebahagiaan. Bagi al-Farabi, kota yang dimaksudkan untuk meraih kebahagiaan disebut sebagai kota utama (al-madinah

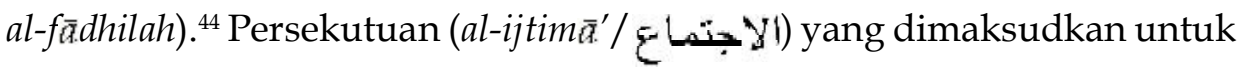
mencapai kebahagiaan disebut sebagai persekutuan utama (الاجنّاع الفاضن). Bangsa yang kota-kotanya bekerjasama untuk meraih kebahagiaan disebut sebagai bangsa utama (الإمة الفاضلة). Dan dunia yang bangsabangsanya saling kerjasama untuk meraih kebahagiaan disebut sebagai

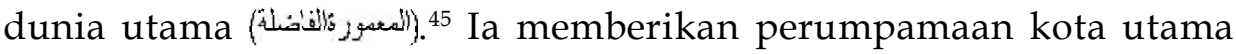
seperti tubuh yang sehat dan sempurna yang anggotanya saling bekerjasama untuk kesehatan hidup sang pemilik tubuh. Pimpinan dari seluruh anggota tubuh menurutnya adalah hati (al-qalb). Begitu juga dengan kota, semua anggotanya memiliki perbedaan fungsi. Di dalamnya ada pemimpin, pembantu sang pemimpin hingga mereka yang berada di level paling bawah. ${ }^{46}$

Dalam negara utama (al-madınah al-fä.dhilah), al-Farabi menjelaskan bahwa pemimpin negara ini bukanlah manusia biasa. Menurutnya, kepemimpinan kota utama mensyaratkan dua hal. Pertama, secara alamiah memiliki bakat bawaan, dan kedua memiliki sifat dan kebiasaan yang mendukung bakat alamiahnya. ${ }^{47}$ Menurutnya, manusia semacam ini adalah manusia yang paling sempurna di antara manusia-manusia yang lain. ${ }^{48}$ Karakteristik manusia ini kadang juga disebut sebagai manusia sempurna (al-insān al-kāmil). Ia adalah manusia yang mengetahui setiap tindakan yang bisa mengantarkan pada kebahagiaan. Kriteria ini adalah syarat paling pertama. Syarat lainnya adalah kemampuan berbicara yang membangkitkan imajinasi dengan bahasa yang

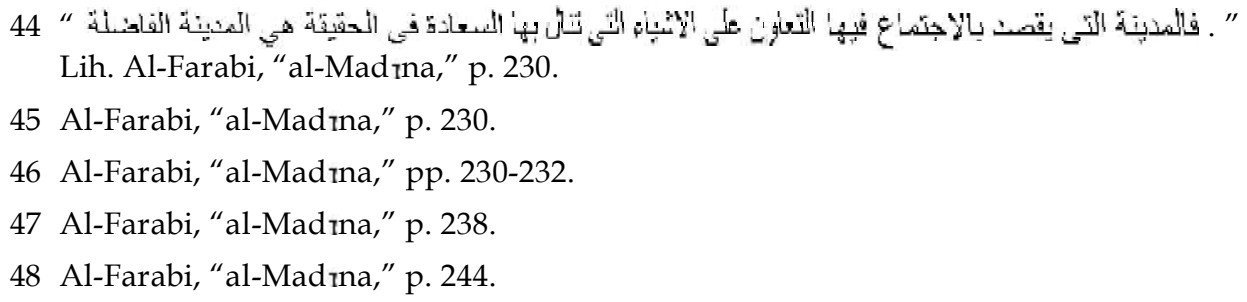


baik, kemampuan memberikan petunjuk agar bisa sampai pada kebahagiaan, dan memiliki fisik yang tangguh agar siap jika harus berperang. Inilah ciri pemimpin pertama yang paling baik untuk kota utama. ${ }^{49}$

Secara lebih spesifik, al-Farabi menyebut dua belas kualitas alamiah yang harus ada pada seorang pemimpin. Dua belas kualitas itu adalah: (1) tubuh yang kuat dan tidak cacat, (2) pemahaman yang baik sehingga bisa mengerti segala sesuatu yang disampaikan kepadanya, (3) ingatan yang baik, (4) kecerdasan, (5) kemampuan diksi yang baik, (6) pencinta ilmu pengetahuan, (7) pencinta kebenaran dan tidak suka kebohongan, (8) tidak candu pada makanan, minuman dan hubungan seksual, juga tidak suka berjudi, (9) memiliki jiwa yang membanggakan dan mencintai kemuliaan (honour/karāmah), (10) memiliki pandangan bahwa uang dan dunia bernilai kecil di matanya, (11) mencintai keadilan dan membenci kezaliman, dan (12) memiliki kehendak kuat untuk mewujudkan sesuatu yang ia anggap harus dilakukan. ${ }^{50}$ Terhimpunnya sifat-sifat ini pada satu orang tentu saja sulit. Karenanya, yang diutamakan adalah manusia yang paling mendekati kualifikasi yang sudah disebutkan. Jika yang paling maksimum hanya ada 6 sifat, di mana yang lain hanya memiliki 5 atau di bawahnya, maka yang memiliki 6 kualifikasi itu adalah yang berhak untuk menjadi pemimpin. ${ }^{51}$ Peran pemimpin tampaknya sangat sentral dalam pemikiran al-Farabi. Dia adalah orang yang mengerti apa yang harus dilakukan oleh warganya untuk meraih kebahagiaan. Terpenuhinya kriteria ini sekaligus menjadi konsep mengenai kedaulatan (sovereign).

Dalam menjelaskan karakteristik kota utama dan kriteria pemimpinnya, al-Farabi tidak menunjuk satu kota tertentu sebagai model. Ia hanya menguraikan kriteria-kriteria yang harus dipenuhi untuk bisa disebut sebagai kota utama. Menurut Walzer, hal yang juga patut digarisbawahi dari pandangan al-Farabi ini adalah bahwa semua kriteria yang disebut-

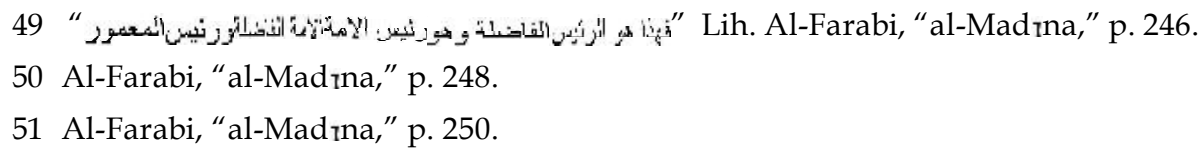


kan di atas sepenuhnya bersifat universal. Bahkan pada level tertentu ia cenderung menghindari istilah-istilah Islam dalam kriteria ini. ${ }^{52}$ Menurut Fakhry, konsep negara ideal al-Farabi ini banyak dipengaruhi oleh pandangan Plato tentang filsuf-raja (philosopher-king). Konsep ini diminati karena memiliki kesesuaian dengan konsep pemerintahan Islam yang dipimpin oleh seorang Imam, yang dalam arti tertentu adalah Nabi dan para penggantinya. Kualifikasi pemimpin pertama menurut Plato memiliki kesamaan dengan kualifikasi yang diharapkan dalam Islam. ${ }^{53}$

Salah satu filsuf Yahudi yang juga banyak dipengaruhi oleh alFarabi, Maimonides, memahami esensi kenabian sebagai emanasi dari Tuhan di mana akal aktif (active intellect) menjadi perantara antara kapasitas rasional dan kapasitas imajinatif. Menurutnya seorang nabi memiliki tiga kapasitas utama, yakni keberanian, relasi dengan yang ilahi dan pengetahuan tentang kebenaran sejati. Karenanya, seorang pemimpin pertama adalah gabungan antar filsuf, negarawan dan nabi. Hukum dalam sebuah negara, sepatutnya merupakan hasil dari kapasitas seorang filsuf, negarawan dan nabi. ${ }^{54}$ Menurut Leo Strauss, dari rumusan ini, secara implisit Maimonides berpendapat bahwa figur Musa merupakan representasi yang paling cocok dari sosok seorang filsufpembuat hukum (philosopher-legislator) dalam pemikiran Plato atau sebagai pemimpin pertama dalam pandangan al-Farabi. ${ }^{55}$

52 Walzer, "Commentary," p. 425

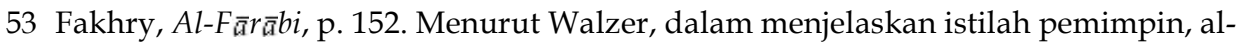
Farabi agak kurang konsisten dalam menyebutnya. Kadang ia menyebutnya dengan istilah $r a^{\prime}$ is dan di lain waktu dengan istilah imam. Ia juga pernah menyebut dengan istilah malik. Lih. Walzer, "Commentary," p. 436. Khusus dengan istilah imam, istilah ini biasanya digunakan untuk para khalifah, pengganti Nabi Muhammad. Walzer, "Commentary," p. 441.

54 Menurut Maimonides, hukum haruslah membangun harmoni atau titik kesetimbangan antara dua titik ekstrem, misalnya antara sikap keras atau kasar dan sikap lembut atau halus. Menurutnya, hukum macam ini hanya bisa dihasilkan oleh seorang filsuf. Hukum tidak boleh diabdikan untuk kenikmatan tubuh manusia sematamata. Hukum harus diarahkan untuk meraih kebahagiaan sebagaimana yang sudah diketahui oleh seorang filsuf. Hukum yang diabdikan untuk memenuhi kepuasan tubuh manusia adalah hukum yang salah. Hukum semacam ini bukanlah produk dari seorang filsuf. Lih. Leo Strauss, "Some Remarks on the Political Science of Maimonides and Farabi" Interpretation, 1990, Vol. 80, No. 1 (1990): pp. 16-17

55 Strauss, "Some Remarks on the Political Science of Maimonides and Farabi", pp. 13-15. 
Dalam menjelaskan kota utama, al-Farabi juga menjelaskan lawanan dari kota utama. Menurutnya, lawan dari kota utama itu adalah kota jahiliah, kota fasiq dan kota sesat. Orang-orang atau para warga yang hidup di dalamnya juga kebalikan dari orang-orang yang ada di dalam kota utama. Dalam pandangannya, kota jahiliah adalah kota yang warganya tidak mengetahui kebahagiaan, dan jika diberitahu, mereka tidak mengerti. ${ }^{56}$ Kota jahiliah itu terbagi menjadi beberapa kota di antaranya adalah kota al-dharuriyat, kota buruk (al-nadzālah), kota hina, kota kemuliaan, kota kekuasaan dan kota demokratis (al-jama'́iyah). Kota al-dharuriyat adalah kota yang warganya hanya berjuang untuk memenuhi kelangsungan badani, seperti makanan, minuman, pakaian, tempat tinggal, kebutuhan seksual dan mereka saling bekerjasama untuk meraih itu. Kota buruk (al-nadzālah) adalah kota yang warganya bekerjasama untuk mengejar kemakmuran dan kekayaan. Masyarakat di kota ini tidak menjadikan kekayaan untuk sesuatu yang lain. Kekayaan menjadi tujuan pada dirinya. Kota yang hina adalah kota yang warganya hanya mengejar kenikmatan badani. Kota kemuliaan adalah kota yang warganya hanya mengejar kemuliaan dan kemasyhuran. Kota kekuasaan adalah kota yang warganya ingin kekuasaan dan mencegah yang lain untuk berkuasa atasnya. Kota demokratis (al-jamā'iyah) dipahami sebagai kota yang warganya menghendaki kebebasan untuk melakukan sesuatu yang mereka inginkan. ${ }^{57}$

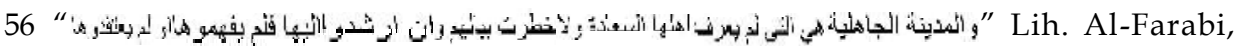
“al-Madına," p. 254.

57 Al-Farabi, “al-Madına,” pp. 252-256. Plato dan Aristoteles juga memahami pemerintahan demokratis dengan penilaian negatif. Plato menggambarkan rakyat kota Athena saat itu yang dianggap demokratis sebagai orang bodoh, mudah tertipu dan seperti orang tua yang terlampau penurut. Namun sebagian penafsir filsafat Plato kurang sepakat dengan pandangan ini. Peter Euben misalnya, ia menilai dialogdialog Plato sebagai ekspresi dari model demokrasi ala Habermasian. Dalam proses pengambilan keputusan, semua pihak terlibat dalam diskusi yang sangat terbuka dengan hak dan kebebasan yang setara. Dalam Plato on Democracy, Thanassis Samaras membandingkan pandangan Plato mengenai demokrasi dalam Republic dan dalam Laws. Dalam Republic, Plato berpendapat bahwa demokrasi dianggap tidak efisien secara politik dan destruktif secara moral. Karenanya ia menolak sistem ini secara tegas dalam buku itu. Sementara dalam Laws, pandangannya mengenai demokrasi berubah. Pada level tertentu, sistem demokrasi telah berkontribusi membentuk kota Yunani menjadi lebih manusiawi. Lih. Malcolm Schofield, Plato: Political 
Lawanan lain dari kota utama adalah kota fāsiq. Kota ini adalah kota yang penduduknya memiliki pandangan yang sama dengan warga kota utama di mana mereka mengetahui dan meyakini pandangan kota utama, namun perilakunya ada di level kota jahiliah. Kota yang juga disebut pada bagian ini adalah kota al-mubaddilah. Kota ini adalah kota yang di masa lalu pandangan dan tindakannya sesuai dengan kota utama, namun kini warga kota itu sudah berubah menjadi kota jahiliyah. Dan terakhir adalah kota sesat (al-dhällat). Di dalam kota ini para warga sebenarnya menghendaki kebahagiaan, namun sayangnya mereka dipimpin oleh pemimpin yang pandangannya salah dan secara sengaja melakukan penipuan dan kecurangan. ${ }^{58}$ Dalam mengomentarai Republic Plato, al-Farabi pernah mengatakan bahwa orang yang hidup dalam negara yang salah (korup), maka kehidupannya tidak merefleksikan kehidupan manusia (yang sejati). Warga yang hidup dalam kota ini perlu mencari atau membangun tempat yang mampu menciptakan kehidupan yang sesuai dengan nilai kemanusiaan sejati. Kehidupan yang sesuai dengan nilai kemanusiaan sejati adalah kehidupan yang adil. Negara yang bisa menjamin kehidupan macam ini hanya ada pada negara yang dipimpin seorang filsuf, karena pemimpin filsuf bisa memberikan hukum yang bersifat ilahi (divine legislation). ${ }^{59}$

\section{RELEVANSI NEGARA UTAMA}

Dari kajian tentang negara utama al-Farabi, adakah gagasan yang bisa dianggap relevan untuk diangkat? Sebagaimana para Aristotelian kontemporer yang tetap melihat adanya relevansi pemikiran Aristoteles untuk saat ini, kita juga bisa menunjukkan beberapa pemikiran dasar al-Farabi dalam al-Madınah al-Fādhilah yang kita anggap relevan. Jika

Philosophy, (Oxford: Oxford University Press, 2006), pp. 53-56; 60; 88-89. Hal yang sama juga bisa kita lihat pandangan Aristoteles mengenai demokrasi. Katanya, demokrasi adalah bentuk deviasi dari dari pemerintahan republik (politeia), karena di dalam sistem demokrasi hanya memberikan perhatian kepada kelompok miskin saja. Lih. Aristoteles, Politics, 1279b 5

58 Al-Farabi, “al-Madına,” pp. 256-258.

59 Strauss, "Some Remarks on the Political Science of Maimonides and Farabi," p. 18. 
kita melihat pandangan al-Farabi di atas, konsep negara-kota utama kiranya menjadi tema sentral dalam pemikirannya. Dalam negara utama, para warga adalah orang-orang yang mengerti hakikat yang baik atau 'the good.' Pemahaman mengenai yang baik (the good) juga harus diiringi oleh kemampuan bertindak baik. Dengan kata lain, yang teoritis dan yang praktis menjadi satu paket keutamaan yang bisa mengantarkan seseorang pada kebahagiaan $\left(a l-s a^{\prime} \bar{a} d a h\right)$. Untuk mewujudkan hal ini, peran seorang filsuf menjadi sangat penting. Karenanya, sebagaimana dalam pandangan Plato, al-Farabi juga berpandangan bahwa selayaknya sang filsuf ini menjadi pemimpin. Seorang pemimpin memiliki tugas mendidik warganya agar bisa mengerti hakikat sebagaimana adanya.

Dari pandangan al-Farabi kita dapat melihat pentingnya asosiasi dan kepemimpinan yang bisa membuat warganya memiliki keutamaan. Secara praktis, pembentukan asosiasi memang untuk saling memenuhi kebutuhan dasar. Namun tujuan yang lebih luhur dari asosiasi adalah pendidikan keutamaan bagi warganya. Al-Farabi, sebagaimana juga Aristoteles, membagi keutamaan menjadi dua, yakni keutamaan intelektual dan keutamaan karakter. Keutamaan intelektual dipahami sebagai pengetahuan teoritis mengenai penyebab pertama (prime cause) dan sifatsifatnya, sementara keutamaan karakter adalah tempaan untuk bersikap dan bertindak sehingga seseorang memiliki kemampuan bersikap dan bertindak secara moderat (tawassuth) atau phronesis (practical reason). Seseorang mengetahui apa yang paling tepat dan pas untuk dilakukan di waktu dan tempat tertentu. Dalam kerja pendidikan itu, peran filsuf tentu saja menjadi sangat penting. Karenanya Plato mengidealkan agar sang filsuf menjadi pemimpin. Lantas apakah untuk konteks saat ini kita masih mengidealkan adanya pemimpin filsuf. Menurut penulis, jika motivasi luhur pembentukan asosiasi sosial dan politik adalah untuk pendidikan keutamaan maka sepatutnya sang pemimpin adalah orang yang mengerti dan sekaligus teladan keutamaan.

Namun hal yang harus digarisbawahi dalam konteks politik kontemporer adalah adanya fakta pluralitas nilai dalam masyarakat. Bagaimana keragaman pandangan dan nilai dalam masyarakat dikelola? Dalam 
bingkai keragaman, kita harus menerima fakta bahwa para warga adalah para pribadi yang sudah memiliki konsepsi nilai yang berasal dari komunitas di mana ia hidupdan juga pergulatan pribadinya. Dalam konteks institusi masyarakat politik, hukum yang diproduksi harus merupakan hasil dari proses deliberasi semua pihak secara terbuka. Apa yang diang-gap baik oleh negara (dalam bentuk konstitusi dan hukum), bukanlah produk dari satu kelompok atau satu orang, tetapi hasil dari proses deliberasi semua pihak. Martha C. Nussbaum menjelaskan pemikiran Aristoteles tentang kehidupan yang baik (good life) sebagai produk dari kesepakatan kolektif. Katanya, dalam merefleksikan makna kehidupan yang baik, kita tidak merefleksikan itu hanya dalam bingkai pribadi atau kelompok tertentu saja tetapi harus dalam bingkai kebersamaan. Manusia adalah mahluk sosial, sehingga rumusan kebaikan yang hendak dituju juga harus menjadi kesepakatan kolektif semua anggota masyarakat. Apa yang dianggap baik bukan hanya baik untuk satu orang atau satu kelompok, tetapi juga baik untuk kehidupan manusia secara umum. ${ }^{60}$

Dengan pemahaman di atas, institusi politik dan kepemimpinan harus bisa memfasilitasi lahirnya rumusan kehidupan yang baik dan mengandung nilai-nilai keutamaan publik. Rumusan itu tidak lahir dari satu orang, melainkan dari kesepakatan atau konsensus bersama yang kemudian diterima sebagai cita-cita hidup bersama. Konsensus itu harus merefleksikan keutamaan hidup sebagai warga negara. Dalam kerangka ini, institusi politik harus menjadi tempat penempaan agar para warga bisa memiliki keutamaan kewargaan yang sudah disepakati. Michael J. Sandel merumuskan tujuan politik menurut Aristoteles dalam Justice: What's the Right Thing to Do? Katanya, tujuan tertinggi pembentukan komunitas politik adalah untuk mengembangkan nilai keutamaan kewargaan (civic virtue). Politik memiliki fungsi untuk membuat karakter para warga semakin baik. Mengapa demikian, jawabannya adalah

60 Martha C. Nussbaum, Aristotle's De Motu Animalium, (Princeton: Princeton University Press, 1978), pp. 102-103. 
karena hidup bersosial merupakan aktualisasi dari hakikat manusia sebagai zoon politikon. ${ }^{61}$ Dengan begitu kita bisa memahami bahwa kota utama merupakan tempat untuk menempa warga menjadi pribadi yang memiliki keutamaan kewargaan. Konsepsi mengenai keutamaan dalam konteks kontemporer, sebagaimana disinggung di atas, bukan derivasi dari satu pandangan pribadi atau kelompok tetapi hasil dari deliberasi kolektif.

\section{SIMPULAN}

Karya al-Madīnah al-Fādhilah al-Farabi merupakan gambaran nyata bagaimana besarnya pengaruh filsafat Yunani bagi filsafat atau filsuf Muslim dari abad ke-9 hingga 13. Secara khusus, pengaruh Plato dan Aristoteles adalah yang paling utama. Tentu saja, pengaruh filsafat keduanya itu banyak merupakan hasil olahan dari Plotinus. Karenanya cukup tepat jika dikatakan bahwa pandangan al-Farabi merupakan bagian dari tradisi neoplatonisme dalam Islam. Sementara dalam soal filsafat politik, kita bisa melihat dengan cukup jelas jejak-jejak gagasan Plato dan Aristoteles dalam pemikiran al-Farabi. Konsep Kota Utama barangkali merupakan kesimpulan pembacaan al-Farabi mengenai 'politik' yang diinspirasi oleh dua filsuf Yunani itu. Pentingnya peran filsuf raja, keutamaan pengetahuan, keutamaan karakter, konsep kebahagiaan adalah ide-ide utama yang banyak diambil dari Plato dan Aristoteles. Namun, sebagai seorang filsuf Muslim, gagasan-gagasanitu ia modifikasi dan adaptasi dengan prinsip-prinsip dalam Islam. Peran filsuf raja sebanding dengan peran Nabi dalam memimpin dan mendidik umatnya. Begitu juga dengan konsep kebahagiaan yang tentu berkorelasi dengan tujuan kebahagiaan bagi seorang Muslim yakni perjumpaan atau penyatuan dengan Tuhan.

Hal yang cukup menantang tentu saja bagaimana pandangan klasik ini ditarik untuk masa kontemporer. Apakah gagasan-gagasan yang diajukan masih cukup relevan untuk dunia saat ini? Visi mengenai

61 Sandel, Justice, p. 193. 
asosiasi sosial yang berkeutamaan tentu saja tetap relevan. Namun konsep keutamaan yang diajukan harus lahir dari proses deliberatif para warga yang bebas dan setara. Konsep hidup yang baik (good life) bukanlah konsep metafisik yang diproduk oleh satu kelompok tertentu yang merasa paling memiliki otoritas atas hal itu. Dalam masyarakat majemuk seperti saat ini kita harus sepakat bahwa setiap pihak memiliki kebebasan yang setara (equal liberty). Dengan prinsip kebebasan yang setara, setiap pihak memiliki hak terlibat dalam kehidupan publik untuk memutuskan tujuan-tujuan hidup bersama. Dengan demikian, kehidupan yang baik jelas bukan representasi satu kelompok, tetapi merupakan hasil dari proses deliberatif secara kolektif, terbuka dan bebas. Dari al-Farabi kita tetap mendapatkan inspirasi mengenai pentingnya asosiasi sosial yang berkeutamaan. Hanya saja, gagasan itu harus mengadaptasi tuntutan prinsip kebebasan yang setara bagi masyarakat majemuk. Jika tidak, gagasan keutamaan bisa saja dibajak oleh gagasan metafisik yang anti terhadap keragaman pandangan dan nilai.

\section{DAFTAR PUSTAKA}

Al-Farabi, Abu Nasr, "Mabādi $\Lambda$ rā Ahl al-Madīna al-Fādila," hal. 38329, dalam Richard Walzer, Al-Farabi on the Perfect State, Teks Revisi, Pengantar, Terjemahan dan Komentar, Oxford: Clarendon Press, 1985.

Al-Ghazāl̄̄, Tahāfut al-Falāsifah, Sulaiman Dunyā (ed.) Kairo: Dār alMa'ārif, 1972.

Aristotle, Politics, diterjemahkan oleh C.D.C. Reeve, Cambridge: Hacket Publishing Company, 1998.

Aristotle, Nicomachean Ethics, diterjemahkan dan diedit oleh Roger Crisp, Cambridge: Cambridge University Press, 2004.

Fakhry, Majid, Sejarah Filsafat Islam: Sebuah Peta Kronologis, Bandung: Mizan, diterjemahkan dari karya A Short Introduction to Islamic Philosophy, Theology and Mysticism, 2001.

Fakhry, Majid, Al-Fāräubi: Founder of Islamic Neoplatonism, Oxford: One World, 2002.

Ferrari, G. R. F., “Pengantar" dalam Plato, The Republic, diedit oleh G. R. F. Ferrari, diterjemahkan oleh Tom Griffith, Cambridge: Cambridge University Press, 2000. 
MacIntyre, Alasdair, After Virtue: A Study in Moral Theory, edisi ketiga, Indiana: University of Notre Dame Press, [1981] 2007.

Meyer, Frederick, A History of Ancient and Medieval Philosophy, New York: American Book Company, 1950.

Nasution, Harun, Islam Ditinjau Dari Berbagai Aspeknya, Jilid I, UI Press, 1985.

Netton, Ian Richard, Al-Fārāubs and His School, London: Routledge, 1992.

Nussbaum, Martha C., Aristotle's De Motu Animalium, Princeton: Princeton University Press, 1978.

Plato, The Republic, diedit oleh G. R. F. Ferrari, diterjemahkan oleh Tom Griffith, Cambridge: Cambridge University Press, 2000.

Sandel, Michael J., Justice: What's the Right Thing To Do?, New York: Farrar, Straus and Giroux, 2009.

Schofield, Malcolm, 2006, Plato: Political Philosophy, Oxford: Oxford University Press

Shaliba, Jamil, 1970, Tārikh al-Falsafah al-'Arabiyah, Beirut: Dar al-Kitab al-Lubnani

Strauss, Leo, "Some Remarks on the Political Science of Maimonides and Farabi" dalam Interpretation, 1990, Vol. 80, No. 1

Walzer, Richard, 1985, "Commentary," hal. 331-503, dalam Richard Walzer, Al-Farabi on the Perfect State, Teks Revisi, Pengantar, Terjemahan dan Komentar, Oxford: Clarendon Press.

Walzer, Richard, 1985, "Introduction" hal. 1-18, dalam Richard Walzer, Al-Farabi on the Perfect State, Teks Revisi, Pengantar, Terjemahan dan Komentar, Oxford: Clarendon Press. 